\title{
THE USE OF NON-TRADITIONAL RAW MATERIALS AT MAKING SOUR-MILK PRODUCTS
}

\author{
Yana Biletska ${ }^{1}$ \\ ya.belecka@karazin.ua \\ Galina Dyukareva \\ Department of Merchandising in Customs Affairs \\ Kharkiv State University of Food Technology and Trade \\ 333 Klochkivska str., Kharkiv, Ukraine, 61051 \\ d.galina@gmail.com \\ Natalia Danko \\ n.danko@karazin.ua \\ ${ }^{1}$ Department of International E-Commerce and Hotel\&Restaurant Business \\ V. N. Karazin Kharkiv National University \\ 4 Svobody sq., Kharkiv, Ukraine, 61022
}

\begin{abstract}
The results of using flour of sprouted soya and chickpea at making sour-milk products, based on goat milk, are presented. The object of the study is sour milk products, based on goat milk with using flour of sprouted leguminous, enriched with iodine and selenium with the associated use of acidophilic baccilus Lactobacillus acidophilus and bifidobacteria Bifidobacterium lactis.

One of today problems is a deficiency of iodine and selenium, coming to the human organism with food in organically available forms. In this connection the development of new sour-milk products that are carriers of organic forms of microelements with organoleptic characteristics, usual for consumers, is an important task. At the research the dependence of changes of organoleptic parameters of sour-milk product quality has been established.

It has been determined, that it is expedient to use flour, enriched with iodine and selenium in amount $2 \%$ of the sour-milk product mass. Introduction of the aforesaid amount of flour in a sour-milk product favors the improvement of organoleptic parameters and gives developed products a special dietetic destination. At consuming $100 \mathrm{~g}$ of a sour-milk vegetable product, 16.8 and $24.5 \%$ of the daily need in iodine and selenium (respectively) is covered.

Based on the obtained results, the recipe of a sour milk product that provides the use of goat milk in amount $93 \%$, flour of sprouted leguminous (1:1) in amount $2 \%$, acidophilic bacillus Lactobacillus acidophilus and bifidobacteria Bifidobacterium lactis in amount $5 \%$ of the product mass has been elaborated.

Comparing with analogous known methods, the offered method provides a series of advantages. The most important of them are organoleptic parameters of a ready product, usual for consumers, and its safe enrichment with iodine and selenium. It takes place at the expanse of using organic forms of microelements that excludes a possibility of accumulation in the organism.
\end{abstract}

Keywords: flour, soya, chickpea, iodine, selenium, goat milk, sour-milk product, bifidobacteria.

DOI: $10.21303 / 2504-5695.2020 .001371$

\section{Introduction}

A promising direction in creation of new food products is the combination of milk and vegetable raw materials, able to fill the deficiency of necessary substances, important to our organism [1]. It is possible to consider sour-milk products as a base for developing specialized products, providing the human organism with not only, proteins, lipids and carbohydrates, but also iodine and selenium.

More than $17 \%$ of the Earth population suffers from the lack of essential micronutrients, among which iodine and selenium are at the first place [2].

For overcoming this problem, it is possible to use flour of sprouted leguminous that are carriers of organic iodine and selenium in amounts 126 and $75 \mathrm{mcg}$ (respectively) for making sourmilk products.

The conduction of this research complex allows to widen the assortment of sour-milk products for special dietetic consumption. It gains a special importance regarding the possible use of developed products in rations of people with endocrine system disorders. 


\section{Analysis of literary data and statement of the problem}

Modern development tendencies of milk industry provide correction of the products' composition by combining milk raw materials with components of the vegetable origin [6-8]. Of special interest in this context are grain and leguminous plants that are a source of vitamins, mineral substances and other biologically active ones, delivered to the human organism [9, 10]. Scientists developed milk-vegetable yoghurt, using flour of flax seeds, cedar nuts, pumpkin and wheat. It was established, that the optimal dosage of their joint use is $2 \%$.

The product has improved quality parameters, comparing with the control and is provided with treating-prophylactic properties. A shortcoming of the offered recipe is the absence of organic forms of microelements (iodine and selenium), which deficiency is observed in $17 \%$ of the world population [11].

The well-known method of enriching sour-milk products with iodine is to introduce kelp powder in their composition [12]. Kelp is introduced in cow milk in amount $0.2 \%$ of the milk mass. Scientists established that kelp powder introduction gives sour-milk products a certain piquant smack, inherent to seaweed.

Products, made by the developed recipe, are classified as ones of a special destination. A shortcoming of this method is an unessential amount of iodine, delivered to the organism $-7.5 \mathrm{mcg}$ and as a result the small $\%$ of daily need satisfaction that is only $5 \%$. And the use of cow milk that has in its composition the high content of $\alpha \mathrm{s} 1$ - casein factions of proteins that cause allergic reactions in the organism of a human, who is at a dietetic ration, as a base [13, 14].

It is known, that sour-milk products, based on goat milk, are better assimilated than cow ones at the expanse of rational proportion of alpha-s and $\beta$ - casein factions $[15,16]$. A shortcoming of using goat milk at developing sour-milk products is the fact that bifidobacteria develop slower in it than in cow milk. Work [17] proves that combined leavens have a higher biochemical activity and stability, comparing with ones, produced on monocultures. One of causes of the bad growth of bifidobacteria is different compositions of casein factions, creating favorable conditions for propagation only after partial hydrolysis of caseins. As a result of casein disintegration, polypeptides, glycopeptides, amino sugars that stimulate the growth of bifidobacteria form [18]. It is possible to solve this problem at the expanse of using Lactobacillus acidophilus and Bifidobacterium lactis cultures. As far as there are no enough data about using flour of sprouted leguminous, enriched with iodine and selenium, at making sour-milk products, based on goat milk, it is necessary to deepen and widen researches in this direction.

\section{Research aim and tasks}

The aim of the research is to use flour of sprouted leguminous, enriched with iodine and selenium, at making sour-milk products.

The following tasks were set for attaining this aim:

- to study quality parameters of sour-milk products with flour of sprouted leguminous;

- to determine the content of iodine and selenium in sour-milk products with using sprouted leguminous flour.

To develop the recipe of a sour-milk vegetable product, containing sprouted leguminous flour, based on the results of the conducted studies.

\section{Materials and methods of the research}

The research objects were «Food soya flour, enriched with iodine» TC U 10.6-0271205001:2019, «Food chickpea flour, enriched with selenium» TC U 10.6-0271205-002:2019. Flour was used in ratio 1:1. Strains of microorganisms of acidophilic bacillus (Lactobacillus acidophilus) and bifidobacteria (Bifidobacterium lactis). Milk of goats of the breed "Zaanenska", bred at the farm "Grandmother's goats", Kyiv region, v. Galaiky. Samples of daily yield of milk were used.

The characteristic of experimental samples: control - without using flour of sprouted leguminous. Experiment 1 - goat milk $93.5 \%$, flour of sprouted leguminous (1:1) in amount $1.5 \%$, acidophilic bacillus Lactobacillus acidophilus and bifidobacteria Bifidobacterium lactis (leaven) in amount $5 \%$ of the product mass. Experiment 2 - goat milk $93 \%$, flour of sprouted legu- 
minous (1:1) in amount $2 \%$, acidophilic bacillus Lactobacillus acidophilus and bifidobacteria Bifidobacterium lactis (leaven) in amount $5 \%$ of the product mass. Experiment 3 - goat milk $92.5 \%$, flour of sprouted leguminous (1:1) in amount $2.5 \%$, acidophilic bacillus Lactobacillus acidophilus and bifidobacteria Bifidobacterium lactis (leaven) in amount $5 \%$ of the product mass.

\section{1. Study of the dependence of the change of organoleptic parameters of a sour-milk product on \% of using flour of sprouted leguminous}

The dependence of the change of organoleptic parameters was determined at the open tasting. Qualified specialists, acquainted with the production technology of milk and sour-milk products and tasting rules, participated in the work. A sour-milk vegetable product was tested by such parameters as color, taste and smell, consistence, fermentation time, clot characteristic. The products were assessed by the verbal and point systems of gustatory marks, by five-point scale.

\section{2. Determination of the mass share of iodine and selenium in samples of sour-milk} products with different $\%$ of using flour of sprouted leguminous

The mass share of iodine was determined using the voltamperometric analyzer «ABA-2» $(\mathrm{Bu}-$ revestnik, Russia). The mass share of selenium was determined using the voltamperometric analyzer «ABA-3» (Burevestnik, Russia). The determination of the mass share of the microelements was conducted by the method of standard tests and additives. The sample batch was processed by the potassium hydroxide solution, burnt on the electric stove, then ashed, using the system for microwave ashing «PHOENIX» (Daewoo, China). The obtained ash was mixed up in water, neutralized to $\mathrm{pH} 4$...6, centrifuged. The obtained mass was introduced to the electrochemical cup with a background solution and measured. The mass share of the studied microelements was calculated by the obtained results.

\section{Research results and their discussion}

The study of organoleptic parameters of sour-milk products is presented in Table $\mathbf{1 .}$

Table 1

Quality parameters of sour-milk products with using flour of sprouted leguminous

\begin{tabular}{|c|c|c|c|c|c|}
\hline \multirow{2}{*}{$\begin{array}{l}\text { Experimental } \\
\text { sample }\end{array}$} & \multicolumn{5}{|c|}{ Quality parameters of a sour-milk product } \\
\hline & Color & Taste and smell & Consistence & $\begin{array}{l}\text { Fermentation } \\
\text { time, hours }\end{array}$ & Clot characteristic \\
\hline Control & White & Pure, sour-milk & $\begin{array}{l}\text { Viscous, dense, homoge- } \\
\text { nous }\end{array}$ & 4.0 & $\begin{array}{l}\text { Even without whey } \\
\text { separation }\end{array}$ \\
\hline Experiment 1 & Beige & Sour-milk & Viscous, homogenous & 4.0 & $\begin{array}{l}\text { Even without whey } \\
\text { separation }\end{array}$ \\
\hline Experiment2 & Creamy & $\begin{array}{l}\text { Sour-milk with a light smack } \\
\text { of an additive }\end{array}$ & $\begin{array}{l}\text { Viscous, homogenous with } \\
\text { inclusions }\end{array}$ & 3.5 & $\begin{array}{l}\text { Even without whey } \\
\text { separation }\end{array}$ \\
\hline Experiment 3 & Creamy & $\begin{array}{l}\text { Sour-milk smack of bifidobac- } \\
\text { teria is brightly expressed }\end{array}$ & $\begin{array}{l}\text { Viscous, homogenous with } \\
\text { inclusions, }\end{array}$ & 3.0 & $\begin{array}{l}\text { Even, glass-like without } \\
\text { whey separation }\end{array}$ \\
\hline \multicolumn{6}{|c|}{$\begin{array}{l}\text { Note*: control - without using flour of sprouted leguminous; Experiment } 1 \text { - goat milk } 93.5 \% \text {, flour of sprouted leguminous (1:1) } \\
\text { in amount } 1.5 \% \text {, acidophilic bacillus Lactobacillus acidophilus and bifidobacteria Bifidobacterium lactis (leaven) in amount } 5 \% \\
\text { of the product mass; Experiment } 2 \text { - goat milk } 93 \% \text {, flour of sprouted leguminous (1:1) in amount } 2 \% \text {, acidophilic bacillus Lac- } \\
\text { tobacillus acidophilus and bifidobacteria Bifidobacterium lactis (leaven) in amount } 5 \% \text { of the product mass; Experiment } 3 \text { - goat } \\
\text { milk } 92.5 \% \text {, flour of sprouted leguminous (1:1) in amount } 2.5 \% \text {, acidophilic bacillus Lactobacillus acidophilus and bifidobacteria } \\
\text { Bifidobacterium lactis (leaven) in amount } 5 \% \text { of the product mass }\end{array}$} \\
\hline
\end{tabular}

Analyzing the indices, it has been established, that for fermenting the samples with using $1.5 ; 2$; $2.5 \%$ of the developed flour, 4; 3, 5 and 3 hours are needed, the control sample was fermented during 4 hours. All experimental samples have a color from white to creamy, the consistence of the control sample is viscous, dense, homogenous with the increased $\%$ of using flour of sprouted leguminous, their 
inclusions appear. For fermenting samples with using $2 . .2 .5 \%$ of the flour, $3 . .3 .5$ hours are needed that is by $0.5 \ldots 1$ hour lower, comparing with time that must be spent for fermenting the control sample. The characteristic of a clot in the samples, where flour of sprouted leguminous is used in amount $1.5 \ldots 2.0 \%$ is even without whey separation. The use of flour of sprouted leguminous in amount $2.5 \%$ of the flour mass influences the worsening of the usual taste and smell of a sour-milk product. A sour-milk smack of bifidobacteria, rather brightly expressed appears in the samples (Table 1).

The determination of the mass share of iodine and selenium in the samples of sour-milk products with different $\%$ of using flour of sprouted leguminous is presented in Table 2.

Table 2

The content of iodine and selenium in a sour-milk product with using flour of sprouted leguminous

\begin{tabular}{cccc}
\hline Experimental sample & Mass share of iodine, mcg & Mass share of selenium, mcg & Organoleptic mark, points (max 5) \\
\hline Control & - & - & 4.9 \\
Experiment 1 & $18.9 \pm 0.2$ & $10.5 \pm 0.1$ & 4.9 \\
Experiment 2 & $25.2 \pm 0.1$ & $14.0 \pm 0.1$ & 5.0 \\
Experiment 3 & $31.5 \pm 0.2$ & $17.5 \pm 0.2$ & 3.5
\end{tabular}

Note: * the characteristic of the experimental samples is given in subsection 4 and in the note under Table 1. The daily need in iodine is $150 \mathrm{mcg}$, selenium $55 \mathrm{mcg}$. The standards are given for adult women. The iodine deficiency forms, if the amount of daily consumption is lower $10 \mathrm{mcg}$ [19]

It has been established, that products with using $1.5 \%$ of flour of sprouted leguminous satisfy $12.6 \%$ of the need in iodine and $19 \%$ - in selenium, have good organoleptic parameters (4.9 points). Products with using $2 \%$ of flour of sprouted leguminous satisfy $16.8 \%$ - in iodine and $24.5 \%$ - in selenium, have perfect organoleptic parameters (5 points). Products with using $2.5 \%$ of flour of sprouted leguminous satisfy $21 \%$ - in iodine and $31.8 \%$ - in selenium. But there is observed the worsening of organoleptic parameters (3.5 points), "non-classic" taste and smell with the brightly expressed smack of bifidobacteria appears in sour-milk products.

It is expedient to use flour of sprouted leguminous at producing a sour-milk vegetable product in amount $2 \%$. It doesn't influence the change of organoleptic parameters and enriches a product with iodine and selenium, in such a way giving it a special dietetic destination.

Based on the conducted studied, there has been elaborated the recipe of a sour-milk product, according to which goat milk is used in amount $93 \%$, flour of sprouted leguminous (1:1) in amount $2 \%$, acidophilic bacillus Lactobacillus acidophilus and bifidobacteria Bifidobacterium lactis (leaven) in amount $5 \%$ of the flour mass.

We use the classic technology of sour-milk products by the thermostatic way [20]. Warm goat milk to $t-35 \ldots 40^{\circ} \mathrm{C}$. Introduce flour of sprouted leguminous and leaven. Fermentation is conducted at $40^{\circ} \mathrm{C}$, during 3 hours. Cool to $t-(25 \pm 2){ }^{\circ} \mathrm{C}$ during 6 hours. Keep at $t-(6 \pm 1){ }^{\circ} \mathrm{C}$.

The prospect for further studies is to investigate quality parameters of a ready product and its correspondence to normative-technical documents.

\section{Conclusions}

The dependence of the change of organoleptic quality parameters of a sour-milk product has been established. It has been determined that it is expedient to use sprouted leguminous flour at making sour-milk products in amount $2 \%$. The use of such amount doesn't influence the worsening of organoleptic parameters and gives developed products a special dietetic destination. It has been established, that it is rational to use sprouted leguminous flour in amount $2 \%$ of the sour-milk product mass.

At these ratios of the recipe components at consumption of $100 \mathrm{~g}$ of a product per day, 16.8 and $24.5 \%$ of the daily need of the human organism in iodine and selenium (respectively) is satisfied.

The recipe of a sour milk product that provides the use of goat milk in amount $93 \%$, flour of sprouted leguminous (1:1) in amount $2 \%$, acidophilic bacillus Lactobacillus acidophilus and bifidobacteria Bifidobacterium lactis in amount $5 \%$ of the product mass has been developed. 


\section{References}

[1] Biletska, Y., Perepelytsia, A., Bilovska, O. (2020). Determination of consumer preferences of different groups of food. EUREKA: Social and Humanities, 1, 23-26. doi: https://oi.org/10.21303/2504-5571.2020.001136

[2] Moliboga, E. A. (2016). Expansion of variety line of functional food products by developing technologies of processed cheese product for specialized nutrition. Agrarniy vestnik Urala, 05 (147), 74-77.

[3] Biletska, Y., Plotnikova, R., Skyrda, O., Bakirov, M., Iurchenko, S., Botshtein, B. (2020). Devising a technology for making flour from chickpea enriched with selenium. Eastern-European Journal of Enterprise Technologies, 1 (11 (103)), 50-58. doi: https://doi.org/10.15587/1729-4061.2020.193515

[4] Beletska, Y., Plotnikova, R., Bakirov, M., Vereshchynskyi, O. (2020). Development of the technology of soya flour enriched with iodine. Food Science and Technology, 14 (2). doi: https://doi.org/10.15673/fst.v14i2.1487

[5] Biletska, Y., Djukareva, G., Ryzhkova, T., Kotlyar, O., Khaustova, T., Andrieieva, S., Bilovska, O. (2020). Substantiating the use of germinated legume flour enriched with iodine and selenium in the production of cooked-smoked sausages. Eastern-European Journal of Enterprise Technologies, 3 (11 (105)), 46-54. doi: https://doi.org/10.15587/1729-4061.2020.204796

[6] Ryzhkova, T., Bondarenko, T., Dyukareva, G., Biletskaya, Y. (2017). Development of a technology with an iodine-containing additive to produce kefir from goat milk. Eastern-European Journal of Enterprise Technologies, 3 (11 (87)), 37-44. doi: https:// doi.org/10.15587/1729-4061.2017.103824

[7] Greppi, G. F., Roncada, P., Fortin, R. (2008). Protein components of goat's milk. Dairy goats feeding and nutrition, 71-94. doi: https://doi.org/10.1079/9781845933487.0071

[8] Garneau, S., Martin, N. I., Vederas, J. C. (2002). Two-peptide bacteriocins produced by lactic acid bacteria. Biochimie, 84 (5-6), 577-592. doi: https://doi.org/10.1016/s0300-9084(02)01414-1

[9] Mamaeva, L. A., Kasimova, M. K., Alibekov, R. S., Usenova, S. O., Sopin, V. F. (2014). Standartizatsiya metoda polucheniya kislomolochnogo produkta s dobavleniem proroshchennoy pshenitsy. Vestnik Kazanskogo tehnologicheskogo universiteta, 17 (9), $218-220$.

[10] Biletska, Y., Ryzhkova, T., Perepelytsia, A., Husliev, A. (2020). Investigation of the conservation of vitamins and microelements during storage in boiled-smoked sausages with enriched leguminous flour. EUREKA: Life Sciences, 3, 26-30. doi: https://doi.org/10.21303/2504-5695.2020.001320

[11] Kanareykin, V., Berezov, V., Bikbova, R. (2016). Noviy funktsional'niy molochno-rastitel'niy yogurt. Aktual'nye problemy intensivnogo razvitiya zhivotnovodstva. Available at: https://cyberleninka.ru/article/n/novyy-funktsionalnyy-molochno-rastitelnyy-yogurt

[12] Okhotnikov, S. I. (2017). Iodine enrichment of thermal acid cheeses by means of introduction the kelp in their structure. Vestnik of the Mari State University. Chapter «Agriculture. Economics», 3 (2 (10)), 39-43.

[13] Fatikhov ,A. G., Haertdinov, R. A. (2017). Influence of the level of content of $\alpha$ S1- and $\beta$ - casesins in goat milk on its allergenic, thermostable, suitability of cheese properties. Uchenye zapiski Kazanskoy gosudarstvennoy akademii veterinarnoy meditsiny im. N.E. Baumana, 126-167. Available at: https://cyberleninka.ru/article/n/vliyanie-urovnya-soderzhaniya-s1-ikazeinov-v-koziem-moloke-na-ego-allergennye-termostabilnye-i-syrodelcheskie-svoystva

[14] Shuvarikov, A. S., Yurova, E. A., Pastukh, O. N. (2017). Quality indicators of cow, goat and camel milk with account of allergenicity. Izvestiâ Timirâzevskoj Sel'skohozâjstvennoj Akademii, 5, 115-123. doi: https://doi.org/10.26897/0021-342x-2017-5-115-123

[15] Fatikhov, A. G., Haertdinov, R. A. (2016). technological properties goat milk. Uchenye zapiski Kazanskoy gosudarstvennoy akademii veterinarnoy meditsiny im. N.E. Baumana, 217-220. Available at: https://cyberleninka.ru/article/n/tehnologicheskie-svoystva-koziego-moloka

[16] Fuller, R., Gibson, G. R. (1998). Probiotics and prebiotics: microflora management for improved gut health. Clinical Microbiology and Infection, 4(9), 477-480. doi: https://doi.org/10.1111/j.1469-0691.1998.tb00401.x

[17] Russell, D. A., Ross, R. P., Fitzgerald, G. F., Stanton, C. (2011). Metabolic activities and probiotic potential of bifidobacteria. International Journal of Food Microbiology, 149 (1), 88-105. doi: https://doi.org/10.1016/j.jffoodmicro.2011.06.003

[18] Gibson, G. R., Fuller, R. (2000). Aspects of In Vitro and In Vivo Research Approaches Directed Toward Identifying Probiotics and Prebiotics for Human Use. The Journal of Nutrition, 130 (2), 391S-395S. doi: https://doi.org/10.1093/jn/130.2.391s

[19] Chym popovnyty defitsyt yodu v orhanizmi. Porady vid MOZ. Available at: http://tvoemisto.tv/news/chym_popovnyty_defitsyt_yodu_v_organizmi_porady_vid_moz_98309.html

[20] Rybak, O. M. (2014). Tekhnolohiyi moloka i molochnykh produktiv. Ternopil. Available at: http://elartu.tntu.edu.ua/bitstream/123456789/20516/1/\%D0\%BA\%D0\%BE\%D0\%BD\%D1\%81\%D0\%BF\%D0\%B5\%D0\%BA\%D1\%82\%20\%D0\% BC\%D0\%BE\%D0\%BB\%D0\%BE\%D0\%BA\%D0\%BE\%20\%D0\%97\%D0\%A2\%D0\%A5\%D0\%9F.pdf (http://creativecommons.org/licenses/by/4.0). 